OPEN ACCESS

Edited by:

Xing Huang,

Nanjing Agricultural University, China

Reviewed by:

Hai-Ming Zhao,

Jinan University, China

Muhammad Rizwan UI Haq,

King Faisal University, Saudi Arabia

Yanling Ma,

Northwest University, China

${ }^{*}$ Correspondence:

Shaohua Chen

shchen@scau.edu.cn

Specialty section:

This article was submitted to

Microbiotechnology,

a section of the journal

Frontiers in Microbiology

Received: 01 January 2020

Accepted: 10 March 2020

Published: 27 March 2020

Citation:

Zhang W, Lin Z, Pang S, Bhatt P and Chen S (2020) Insights Into

the Biodegradation of Lindane $(\gamma$-Hexachlorocyclohexane) Using

a Microbial System.

Front. Microbiol. 11:522.

doi: 10.3389/fmicb.2020.00522

\section{Insights Into the Biodegradation of Lindane $(\gamma$-Hexachlorocyclohexane) Using a Microbial System}

\author{
Wenping Zhang 1,2, Ziqiu Lin 1,2, Shimei Pang 1,2, Pankaj Bhatt ${ }^{1,2}$ and Shaohua Chen 1,2* \\ 'State Key Laboratory for Conservation and Utilization of Subtropical Agro-bioresources, Guangdong Province Key \\ Laboratory of Microbial Signals and Disease Control, Integrative Microbiology Research Centre, South China Agricultural \\ University, Guangzhou, China, ${ }^{2}$ Guangdong Laboratory for Lingnan Modern Agriculture, Guangzhou, China
}

Lindane ( $\gamma$-hexachlorocyclohexane) is an organochlorine pesticide that has been widely used in agriculture over the last seven decades. The increasing residues of lindane in soil and water environments are toxic to humans and other organisms. Large-scale applications and residual toxicity in the environment require urgent lindane removal. Microbes, particularly Gram-negative bacteria, can transform lindane into non-toxic and environmentally safe metabolites. Aerobic and anaerobic microorganisms follow different metabolic pathways to degrade lindane. A variety of enzymes participate in lindane degradation pathways, including dehydrochlorinase (LinA), dehalogenase (LinB), dehydrogenase (LinC), and reductive dechlorinase ( $\mathrm{LinD}$ ). However, a limited number of reviews have been published regarding the biodegradation and bioremediation of lindane. This review summarizes the current knowledge regarding lindane-degrading microbes along with biodegradation mechanisms, metabolic pathways, and the microbial remediation of lindane-contaminated environments. The prospects of novel bioremediation technologies to provide insight between laboratory cultures and largescale applications are also discussed. This review provides a theoretical foundation and practical basis to use lindane-degrading microorganisms for bioremediation.

Keywords: lindane, biodegradation, metabolic pathway, mechanisms, bioremediation

\section{INTRODUCTION}

Lindane ( $\gamma$-hexachlorocyclohexane) is a broad-spectrum organochlorine pesticide belonging to the chlorinated hydrocarbon family. It was synthesized after the Second World War until the 1990s (Saez et al., 2015; Dominguez et al., 2018b). Four major isomers (Figure 1) are formed $(\alpha, \beta, \gamma$, and $\delta)$ during the production of hexachlorocyclohexane $(\mathrm{HCH})$, however, only the $\gamma$ isomers possess insecticidal properties (Vijgen et al., 2019). For the last seven decades, lindane insecticide has been extensively used worldwide on fruits, vegetables, forest crops, animals, and on animal premises (Jung et al., 2018; Singh and Singh, 2019a). The insecticidal activity of lindane is due to its excitatory action on the nervous system (Sharma et al., 2010; Nolan et al., 2012). 


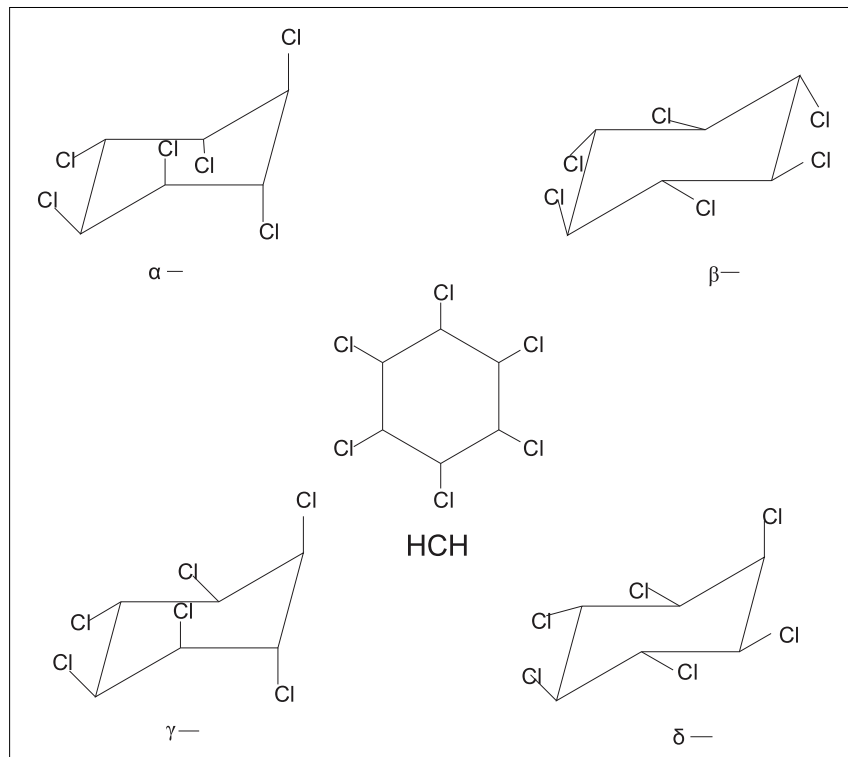

FIGURE 1 | Chemical structures of four hexachlorocyclohexane $(\mathrm{HCH})$ isomers.

Lindane primarily acts on the $\gamma$-aminobutyric acid (GABA) receptor/chloride ionophore complex, which leads to hyperexcitation of the central nervous system (CNS) and results in paralysis, convulsions, and even death (Mladenović et al., 2010; Agrahari et al., 2019). Fractional crystallization is used for the extraction and purification of lindane from the production mixture (Padhi and Pati, 2016). Lindane production is inefficient, as the production of one ton of lindane creates approximately 8-12 tons of other waste isomers, mainly composed of $\alpha$ - and $\beta$-hexachlorocyclohexane (Vijgen et al., 2011).

Lindane can persist in the environment due to its high lipid solubility and chemical stability and can migrate over long distances to cause widespread contamination (Benimeli et al., 2008). The reported half-lives for lindane in soil and water were reported to be 708 and 2292 days, respectively (Beyer and Matthies, 2001). Generally, lindane soil residues enter the food chain and concentrate in the fat tissues of humans and animals causing major health hazards (Nolan et al., 2012). The lipid solubility of lindane increases its toxicity to humans and animals. Lindane has been classified as a carcinogen and endocrine disrupter, and it possesses mutagenic, genotoxic, and teratogenic effects (Markman et al., 2007; Luo et al., 2016; Muñiz et al., 2017).

In 2009, due to the environmental persistency and bioaccumulation potential, lindane, along with its $\alpha$ and $\beta$ isomers, was included in the Stockholm Convention list of persistent organic pollutants (POPs) (Wacławek et al., 2016), and it has been banned or severely restricted. To implement the Stockholm Convention on POPs, the Ministry of Ecology and Environment of China has prohibited the production, circulation, application, import, and export of lindane since 26 March 2019 (Wang, 2019). Lindane is still being used in some developing countries for agricultural and public health purposes

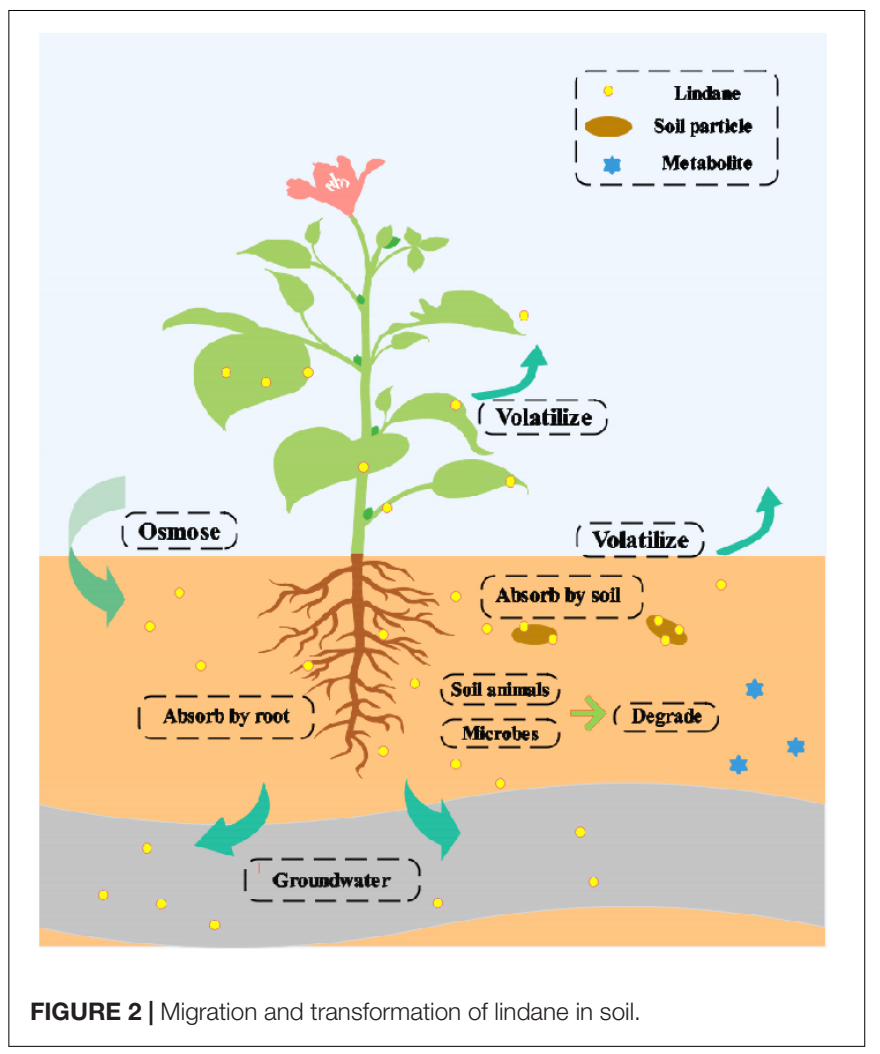

due to its low cost and versatility in pest control (Abhilash and Singh, 2010). Currently, India is the largest producer and consumer of lindane in the world (Sagar and Singh, 2011). Continuous applications and indiscriminate industrial production have led to widespread lindane contamination of soils in the country (Vankar and Ramashanker, 2011). Over the years, only a small portion of the related legal problems were addressed in the European Union (EU) or globally. Large stockpiles of lindane and its wastes are still present in the soil, which represents a large contaminant reservoir (Vijgen et al., 2019). Therefore, lindane degradation technologies must be developed to decontaminate the polluted soil and water.

The migration and transformation of lindane in the soil is presented in Figure 2. Several factors control the lindane distribution and fate in the fields, including (a) loss by volatilization into the atmosphere, (b) loss through surface runoff, and (c) degradation by soil microbes and animals (Lal et al., 2010; Alvarez et al., 2012; Giri et al., 2014). The natural degradation of lindane is a very slow process and varies according to the environmental conditions (Elcey and Kunhi, 2009). Currently, a variety of treatment methods are available for the removal of lindane, but these all have certain drawbacks (Nagpal and Paknikar, 2006; Nagpal et al., 2008).

Physicochemical methods, such as incineration, electrooxidation, and microwave-induced or chemical oxidation, are not eco-friendly and require large and expensive infrastructure (Liu et al., 2015; Zhan et al., 2020). They also generate highly toxic compounds during the degradation process (Manickam et al., 2006; Usman et al., 2014; Dominguez et al., 2018a,b; 
Jung et al., 2018; Huang et al., 2019). However, the microbial degradation of lindane contamination is attracting increasing attention as a less expensive and more environmentally friendly alternative to conventional treatment methods (Chen et al., 2015; Arora et al., 2017; Bajaj et al., 2017; Cycoń et al., 2017; Zhang H. et al., 2018; Bhatt et al., 2019a). The first report regarding the microbial degradation of lindane was published in 1967. Subsequently, numerous studies reported potential microorganisms for the efficient and rapid bioremediation of lindane-polluted environments (Sangwan et al., 2012; Githinji, 2015; Kumar et al., 2016). However, the literature lacks reviews regarding microbial resources and the mechanism of lindane degradation.

In this review, we emphasize the role of microbial degradation for large-scale bioremediation of lindane contamination. We compile detailed information about the microbial resources, mechanisms, and important enzymes involved in lindane degradation, and the aerobic and anaerobic metabolic pathways are also compared. Additionally, a brief account of recent lindane bioremediation methods is given. This review provides novel insights into the future of the large-scale bioremediation of lindane.

\section{TOXICITY OF LINDANE}

The extensive applications of lindane over the decades resulted in a wide distribution that affects the biota, and lindane is now considered one of the most hazardous POPs (Tsygankov et al., 2019). The chemical persistence and lipophilicity of lindane enable it to accumulate and biomagnify in food chains. On 27 October 2017, the World Health Organization published a list of carcinogens where lindane was categorized as a Group 1 carcinogen (Singh and Singh, 2019a).

Lindane is the most acutely toxic $\mathrm{HCH}$ isomer that affects the central nervous system and endocrine system. Lindane is attributed to various adverse health effects in humans, including immunosuppressive, oxidative, proinflammatory, carcinogenic, neurotoxic, and hormone-disruption effects, and even convulsions and death (Vega et al., 2016). The first evidence of death by lindane toxicity was reported in 1953 (Nolan et al., 2012). Due to the lipophilicity, lindane can infiltrate and accumulate in the brain, human breast milk, and other organs that are rich in fat. Epidemiological and agricultural health studies reported that lindane exposure could be associated with the cancers of the breast, prostate, lung, stomach, colon, rectum, and bladder (Jayaraj et al., 2016; Abolhassani et al., 2019; Mortazavi et al., 2019).

Broad applications of lindane pose serious threats to the environment. Once released, lindane can disseminate to all environmental compartments. Compared with other organochlorine pesticides, lindane is ubiquitous due to the high water solubility and volatility (Zhang et al., 2010). Lindane has a strong adsorption tendency in organic materials; therefore, it is long-lived and can be transported for longranges in the environment (Vega et al., 2016). Lindane contaminants have leached underground for decades, polluting both the surface water and groundwater (Weber et al., 2013). Lindane is a threat to a wide range of environments as it bioaccumulates in microorganisms, invertebrates, fish, birds, and mammals (Vijgen et al., 2018) and threatens human health through the food chain. The microbial community structure has a unique response to pesticide pollution, and recent research found that microbial diversity, richness, and structure undergo changes with lindane concentration (Sun et al., 2019).

\section{POTENTIAL MICROORGANISMS IN LINDANE DEGRADATION}

The bacterial degradation of lindane and other xenobiotics are widely reported (Chen et al., 2012, 2013; Yang et al., 2018; Zhang H. et al., 2018; Bhatt et al., 2020c). Bacterial cells use organic pollutants as a sole source of carbon and nitrogen (Chen et al., 2011, 2014; Zhan et al., 2018b; Lin et al., 2020). Currently, a number of lindane-degrading bacterial strains have been screened, enriched, and domesticated (Table 1), including Microbacterium (Singh and Singh, 2019b), Paracoccus (Sahoo et al., 2019), Achromobacter (Singh and Singh, 2019a), Burkholderia (Kumar, 2018), Rhodococcus (Egorova et al., 2017), Chromohalobacter (Bajaj et al., 2017), Kocuria (Kumar et al., 2016), Staphylococcus (Kumar et al., 2016), Streptomyces (Sineli et al., 2016), Arthrobacter (De Paolis et al., 2013), Azotobacter (Anupama and Paul, 2009), Sphingomonas (Manickam et al., 2008), Xanthomonas (Manickam et al., 2010), Pseudomonas (Kumar et al., 2011), Pseudoarthrobacter (Nagpal and Paknikar, 2006), Klebsiella (Nagpal and Paknikar, 2006), Pleurotus (Dritsa and Rigas, 2013), Fusarium (Sagar and Singh, 2011), and Actinobacteria (Cuozzo et al., 2017).

Bacteria play a pivotal role in lindane biodegradation through chemical and physical interactions that lead to structural changes or complete degradation of the target molecule. Different bacteria were reported to degrade lindane at different rates. Singh and Singh (2019b) isolated and identified rhizospheric bacteria Microbacterium spp. strain P27 from Phragmites karka, which effectively degraded $82.7 \%$ lindane $\left(50 \mathrm{mg} \cdot \mathrm{L}^{-1}\right)$ in 15 days and promoted plant growth as well. Sahoo et al. (2019) isolated Paracoccus sp. NITDBR1 from the agricultural fields of Manipur, which efficiently degraded $90 \%$ lindane (100 $\mathrm{mg} \cdot \mathrm{L}^{-1}$ ) in 8 days by using it as the sole source of carbon for its growth. Kumar (2018) isolated and characterized Burkholderia spp. strain IPL04 from a contaminated site by an enrichment culture method, which degraded 98\% lindane in 8 days. The bacterial degradation of lindane has been extensively studied, however, only a few bacteria are known to completely mineralize lindane.

Fungal biodegradation is also considered an environment friendly approach for the detoxification of POPs in comparison with the traditional physical and chemical methods (Saez et al., 2018). Several studies reported the fungal degradation of lindane (Guillén-Jiménez et al., 2012; Salam et al., 2013; Kaur and Kaur, 2016). Fungi have extracellular enzymes that are relatively non-specific to the substrate and possess strong activity. These 
TABLE 1 | Lindane degradation by various microorganisms.

\begin{tabular}{|c|c|c|c|c|c|}
\hline Species & Microorganism & Concentration of lindane & Degradation rate & Sources & References \\
\hline \multirow[t]{20}{*}{ Bacteria } & Microbacterium sp. P27 & $50 \mathrm{mg} / \mathrm{L}$ & $82.7 \%$ in 15 days & Phragmites karka & Singh and Singh, 2019b \\
\hline & Paracoccus sp. NITDBR1 & 100 mg/L & $90 \%$ in 8 days & Agricultural field & Sahoo et al., 2019 \\
\hline & $\begin{array}{l}\text { Achromobacter sp. strain } \\
\text { A3 }\end{array}$ & 50 mg/L & $88.7 \%$ in 15 days & Acorus calamus & Singh and Singh, 2019a \\
\hline & Burkholderia sp. IPL04 & 100 mg/L & $98 \%$ in 8 days & Soil & Kumar, 2018 \\
\hline & $\begin{array}{l}\text { Rhodococcus } \\
\text { wratislaviensis Ch628 }\end{array}$ & 200 mg/L & $32.3 \%$ in 5 days & Soil & Egorova et al., 2017 \\
\hline & Chromohalobacter sp. LD2 & $50 \mathrm{mg} / \mathrm{L}$ & $89.6 \%$ in 7 days & Soil & Bajaj et al., 2017 \\
\hline & Kocuria sp. DAB-1Y & 10 mg/L & $94 \%$ in 8 days & Soil & Kumar et al., 2016 \\
\hline & $\begin{array}{l}\text { Staphylococcus sp. } \\
\text { DAB-1W }\end{array}$ & 10 mg/L & $98 \%$ in 8 days & Soil & Kumar et al., 2016 \\
\hline & Streptomyces sp. M7 & 1.66 mg/L & $45 \%$ in 7 days & Sediment & Sineli et al., 2016 \\
\hline & Arthrobacte fluorescens & 100 mg/L & $40 \%$ in $72 \mathrm{~h}$ & Soil & De Paolis et al., 2013 \\
\hline & Arthrobacter giacomelloi & $100 \mathrm{mg} / \mathrm{L}$ & $56 \%$ in $72 \mathrm{~h}$ & Soil & De Paolis et al., 2013 \\
\hline & Azotobacter chroococcum & 10 mg/L & Almost complete in 6 days & Farm fields & Anupama and Paul, 2009 \\
\hline & Sphingomonas sp. NM05 & 100 mg/L & $90 \%$ in 7 days & Soil & Manickam et al., 2008 \\
\hline & Xanthomonas sp. ICH12 & 100 mg/L & $100 \%$ in 8 days & Soil & Manickam et al., 2010 \\
\hline & $\begin{array}{l}\text { Pseudomonas aeruginosa } \\
\text { ITRC5 }\end{array}$ & $2 \mathrm{mg} / \mathrm{kg}$ of soil & $76 \%$ in 15 days & Soil & Kumar et al., 2011 \\
\hline & Microbacterium sp. ITRC1 & 200 mg/kg of soil & $96 \%$ in 28 days & Soil & Manickam et al., 2006 \\
\hline & Pseudoarthrobacter sp. & $5 \mathrm{mg} / \mathrm{L}$ & $50.7 \%$ in 7 days & Soil & Nagpal and Paknikar, 2006 \\
\hline & Pseudomonas sp. & $5 \mathrm{mg} / \mathrm{L}$ & $52.2 \%$ in 7 days & Soil & Nagpal and Paknikar, 2006 \\
\hline & Klebsiella sp. & $5 \mathrm{mg} / \mathrm{L}$ & $51.2 \%$ in 7 days & Soil & Nagpal and Paknikar, 2006 \\
\hline & $\begin{array}{l}\text { Arthrobacter citreus } \\
\text { B1-100 }\end{array}$ & 100 mg/L & $100 \%$ in $8 \mathrm{~h}$ & Soil & Datta et al., 2000 \\
\hline \multirow[t]{9}{*}{ Fungi } & Ganoderma lucidum GL-2 & $4 \mathrm{mg} / \mathrm{L}$ & $75.5 \%$ in 28 days & & Kaur and Kaur, 2016 \\
\hline & Pleurotus ostreatus & $2.03 \mathrm{mg} / \mathrm{L}$ & & Rotten wood & Dritsa and Rigas, 2013 \\
\hline & $\begin{array}{l}\text { Fusarium verticilliodes } \\
\text { AT-100 }\end{array}$ & 50 mg/L & $30 \%$ in 7 days & Leaves & Guillén-Jiménez et al., 2012 \\
\hline & Rhodotorula sp. VITJzN03 & $600 \mathrm{mg} / \mathrm{L}$ & $100 \%$ in 10 days & Soil & Salam et al., 2013 \\
\hline & Fusarium poae & 100 mg/L & $56.7 \%$ in 10 days & Soil & Sagar and Singh, 2011 \\
\hline & Fusarium solani & $100 \mathrm{mg} / \mathrm{L}$ & $59.4 \%$ in 10 days & Soil & Sagar and Singh, 2011 \\
\hline & Conidiobolous 03-1-56 & $5 \mathrm{mg} / \mathrm{L}$ & $100 \%$ in 5 days & Soil & Nagpal et al., 2008 \\
\hline & Bjendera audusta & $100 \mathrm{mg} / \mathrm{kg}$ of soil & $69.1 \%$ in 30 days & Soil & Quintero et al., 2007 \\
\hline & Cyathus bulleri, & $5 \mu \mathrm{M}$ & $97 \%$ in 28 days & & Singh and Kuhad, 2000 \\
\hline
\end{tabular}

enzymes catalyze a wide range of reactions to break down lindane, and this might be induced by nutritional constraints (Nagpal et al., 2008).

The ligninolytic extracellular enzyme activity of white rot fungi efficiently degrades lindane. The soil environmental conditions (temperature, moisture content, and $\mathrm{C} / \mathrm{N}$ ratio) and the presence of other microorganisms can affect the biodegradation activity of fungi (Kaur and Kaur, 2016). Kaur and Kaur (2016) reported $75.50 \%$ lindane degradation on the 28th day with the white rot fungus Ganoderma lucidum GL-2 strain grown in liquid-state fermentation. GuillénJiménez et al. (2012) isolated a non-white-rot fungus Fusarium verticillioides AT-100 from the leaves of Agave tequilana using an enrichment technique and then used lindane as the sole source of carbon and energy. This was the first report of lindane degradation by $F$. verticillioides to produce benzoic acid derivatives. Rhodotorula VITJzN03 was isolated from a sorghum cultivation field, and mineralized 100\% lindane within 10 days at an initial concentration of $600 \mathrm{mg} \cdot \mathrm{L}^{-1}$ (Salam et al., 2013).

\section{MICROBIAL METABOLIC PATHWAY OF LINDANE DEGRADATION}

Microbial metabolism can effectively degrade lindane through producing extracellular and intracellular enzymes that directly transform lindane into less toxic and non-toxic compounds (Alvarez et al., 2012). Lindane can be biodegraded under both aerobic and anaerobic conditions, however, it is generally mineralized only under aerobic conditions.

\section{Aerobic Degradation}

Several aerobic microorganisms are known to degrade lindane, and the aerobic degradation pathway of lindane was extensively studied in Sphingobium japonicum UT26 (Nagata et al., 2007). 
UT26 uses lindane as a sole source of carbon and energy under aerobic conditions. Many studies found that the degradation pathways of other aerobic lindane degrading strains are the same or very similar to those in UT26. The main reactions that occur during microbial degradation of lindane include dehydrogenation, dechlorination, hydroxylation, dehydrochlorination, and mineralization (Cuozzo et al., 2017). The proposed aerobic biodegradation pathways of lindane are summarized in Figure 3. The key reaction during microbial degradation of lindane is the removal of the chlorine atom (Lal et al., 2006).

In this pathway, lindane is converted to 1,2,4-trichlorobenzene (1,2,4-TCB), 2,5-dichlorophenol (2,5-DCP), and 2,5dichlorohydroquinone (2,5-DCHQ) by the enzymatic activities of dehydrochlorinase (LinA), halidohydrolase (LinB), and dehydrogenase (LinC). The degradation of lindane to 2,5DCHQ is referred to as an upstream pathway, which is further metabolized through the downstream pathway (Endo et al., 2005). 2,5-DCHQ is converted to $\beta$-ketoadipate by reductive dechlorinase (LinD), ring-cleavage dioxygenase (LinE), and maleylacetate reductase (LinF). Researchers documented $\beta$-ketoadipate as a marker metabolite for the degradation of aromatic ring-containing compounds. The intermediate $\beta$-ketoadipate is further converted to succinyl-coenzyme A (CoA) and acetyl-CoA by succinyl-CoA: 3-oxoadipate CoA transferase (LinGH) and $\beta$-ketoadipyl CoA thiolase (LinJ). Both of these compounds are metabolized in the tricarboxylic acid (TCA) cycle (Nagata et al., 2007; Camacho-Pérez et al., 2012). In addition, other studies reported that lindane can be metabolized by microorganisms to produce pentachlorocyclohexene (PCCH), 3,4,5,6-tetrachloro-1-cyclohexene (TCCH), pentachlorobenzene (PCB), or trichlorobenzene (TCB) (Geueke et al., 2013; Cuozzo et al., 2017).

\section{Anaerobic Degradation}

Several studies reported that the microbial anaerobic degradation of lindane is different from aerobic degradation (Endo et al., 2005; Bashir et al., 2018). Dichloro-elimination and dehydrochlorination appear to be the main processes during the transformation of lindane via tetrachlorocyclohexene (TCCH) into lower chlorinated products under the anoxic conditions of aquifer sediments (Lal et al., 2010). There are two different descriptions of the microbial anaerobic degradation pathways of lindane (Figure 4). Some studies proposed that the degradation proceeds through two dichloroeliminations, resulting in the formation of 3,4,5,6-tetrachloro-1-cyclohexene $(\gamma$-TCCH $)$ followed by 5,6-dichlorocyclohexa-1,2-diene. Chlorobenzene is then produced by a dehydrochlorination reaction (Saez et al., 2017). Another anaerobic degradation pathway produces pentachlorocyclohexene (PCCH) followed by 1,2-dichlorobenzene (1,2-DCB) and 1,3-dichlorobenzene (1,3-DCB) (Quintero et al., 2005a,b). Anaerobic bacteria from the sediments and pure cultures of sulfate-reducing bacteria influenced lindane dehalogenation resulting in the accumulation of final products, such as monochlorobenzene and benzene (Camacho-Pérez et al., 2012).

\section{FUNCTIONAL ENZYMES INVOLVED IN LINDANE DEGRADATION}

Dehalogenases are the key enzymes that degrade various halogenated compounds through cleavage of the carbon chlorine stable bond (Lal et al., 2010). Lindane has six chlorine atoms per molecule and dechlorination is a significant step in its degradation. As shown in Figure 3, the biodegradation of lindane requires the participation of various enzymes. The dehalogenases that degrade lindane are dehydrochlorinase (LinA), dehalogenase (LinB), and reductive dechlorinase (LinD) (Nagata et al., 2007). Dehydrogenase (LinC), ring cleavage oxygenase (LinE), and maleylacetate reductase ( $\mathrm{LinF}$ ), which catalyze the dechlorination of substrates, can also be generally categorized as dehalogenases (Lal et al., 2006).

In general, LinA, LinB, and LinC are upstream pathway enzymes of lindane degradation. LinA is a homotetrameric protein with a molecular mass of $16.5 \mathrm{kDa}$ (Nanasato et al., 2016). LinA belongs to the dehydrohalogenase class of enzymes, which can eliminate $\mathrm{HCl}$ from a substrate molecule to form a double bond (Cuozzo et al., 2017). LinA mediates the first two dehydrochlorination steps of lindane (Manickam et al., 2008). Additionally, LinA does not require cofactors to catalyze its activity and thus is a unique dehydrogenase enzyme that distinguishes between the two previously reported dehydrochlorinases (dichlorodiphenyltrichloroethane (DDT) dehydrochlorinase and 3-chloro-D-alanine dehydrochlorinase).

Unlike LinA, LinB is a monomeric $32 \mathrm{kDa}$ protein located in the periplasm of sphingomonads (Geueke et al., 2013). LinB is a haloalkane dehalogenase of the $\alpha / \beta$-hydrolase family and possesses relatively broad substrate specificity (Janssen, 2004). LinB is a key enzyme for lindane degradation in soil and catalyzes dehalogenation through a hydrolytic mechanism. LinB is responsible for the hydrolytic dechlorination of $1,3,4,6$ tetrachloro-1,4-cyclohexadiene (1,4-TCDN) to 2,5-dichloro2,5-cyclohexadiene-1,4-diol (2,5-DDOL) during the aerobic degradation pathway of lindane (Jan et al., 2005). LinB was found to be involved in the degradation of $\beta$ - and $\delta-\mathrm{HCH}$ up to different levels.

Less is currently known about the third upstream pathway enzyme LinC or any other downstream pathway proteins. LinC $(28 \mathrm{kDa})$ is considered a 2,5-DDOL dehydrogenase in the short-chain alcohol dehydrogenase family (Rinku et al., 2005). A general catalytic mechanism explained that hydride transfer from the substrate to $\mathrm{NAD}^{-}$forms $\mathrm{NADPH}$ and a reduced product [the conversion of 2,5DDOL to 2,5-dichlorohydroquinone (2,5-DCHQ)]. LinD (38.4 kDa), LinE (36.0 kDa), LinF (38.0 kDa), and $\operatorname{LinR}$ $(33.6 \mathrm{kDa})$ (a transcriptional regulator) are associated with the downstream lindane degradation pathway (Lal et al., 2010). In S. japonicum UT26, LinD and LinE were induced by LinR in the presence of 2,5-DCHQ, chlorohydroquinone (CHQ) and hydroquinone (HQ) (Keisuke et al., 2002). As the degradation of lindane can lead to different intermediate compounds, we must also consider key enzymes for the further degradation of commonly reported lindane 

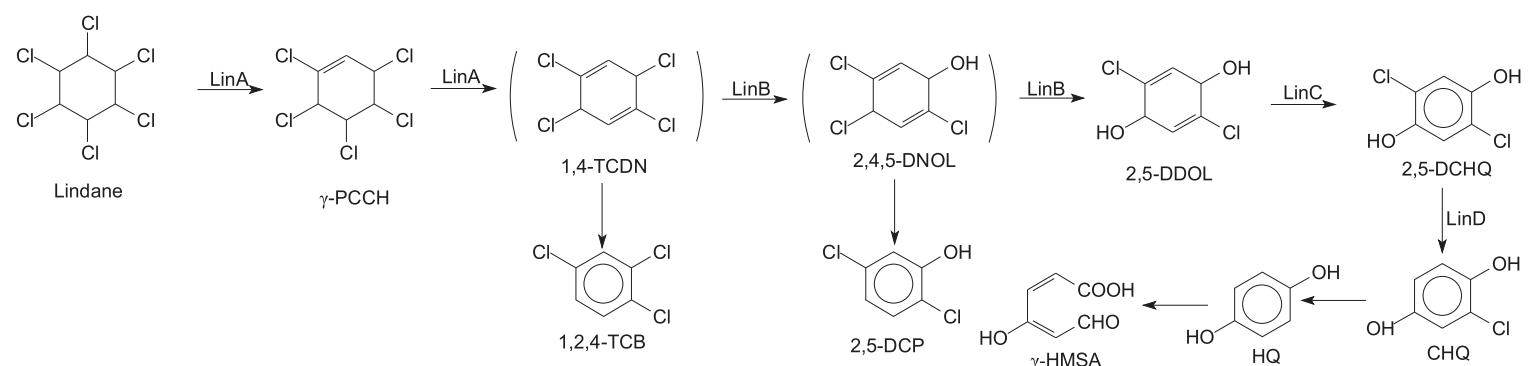

DDOL

2,5-DCP $\quad$-HMSA
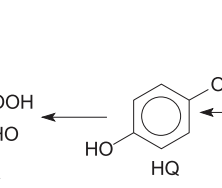

2,5-DCHQ

$\downarrow$ LinD

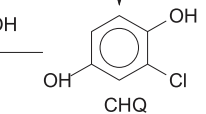

LinE

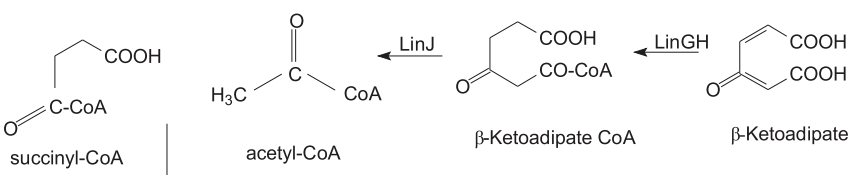

$\stackrel{\operatorname{LinF}}{\longleftarrow}$
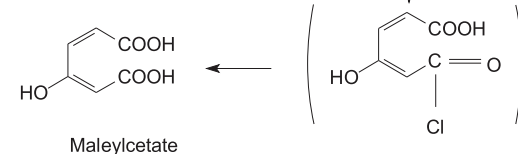

Acylchloride

metabolites. To further understand the mechanisms of lindane biodegradation, it is necessary to explore further key enzymes of lindane degradation.

\section{BIOREMEDIATION OF LINDANE-CONTAMINATED ENVIRONMENTS}

Lindane is an organochlorine pesticide that is highly persistent in the environment due to frequent crop spraying, field applications, accidental spills, domestic wastes, industrial effluents, and garbage dumping (Singh and Singh, 2019b). Lindane residues permeate through the soil surface to the groundwater and cause the extensive pollution of aquatic ecosystems. Lindane accumulation has been reported worldwide and is very toxic to the environment, humans, and animals (Pamela et al., 2011). Therefore, urgent consideration and management of the problem is necessary. Bioremediation is the most promising biotechnological approach to clean polluted environments (Egorova et al., 2017; Zhang J. et al., 2018; Bhatt et al., 2020a). The bacterial strains isolated from sponges demonstrate robustness in lindane degradation. Bacteria associated with the sponge Hymeniacidon perlevis were found to be suitable for lindane degradation. The bacteria isolated belong to Mameliella phaeodactyli, Pseudovibrio ascidiaceicola, Oceanicaulis stylophorae, Ruegeria atlantica, and other uncharacterized genera (Loredana et al., 2017). For lindane bioremediation in samples collected from different polluted sites, researchers applied novel techniques (Asemoloye et al., 2017; Salam et al., 2017; Wang et al., 2019). Pure cultures, microbial consortium, nanobiotechnology, and plantmicrobe interactions are discussed below along with their successful outcomes.

\section{Pure Cultures}

Considering the vast amount of lindane used and the residues in the environment, attempts were made in the past to use pure cultures for the decontamination of lindane. As previously described, a large number of microorganisms with lindane degradation capacity were isolated and characterized (Table 1). Several studies described the application of a single microorganism for the bioremediation of lindane-contaminated soil (Aparicio et al., 2015; Salam et al., 2017). Streptomyces sp. M7 exhibited strong versatility, showing the ability to bioremediate lindane contaminated soil samples at several physicochemical conditions (Aparicio et al., 2015).

The ascomycetous yeast strain Candida VITJzN04 has the ability to degrade $78 \%$ of lindane in garden soils (lindane $\sim 100 \mathrm{mg} / \mathrm{kg}$ ) within 30 days (Salam et al., 2017). The traditional microbial methods are based on the culture dependent approach (Zhan et al., 2018a; Bhatt et al., 2020b). However, the ability of a single microorganism to degrade lindane is influenced not only by its genetic properties but also by the environmental conditions, such as the $\mathrm{pH}$, temperature, concentration of lindane, etc. (Feng et al., 2020).

\section{Microbial Consortium}

A microbial consortium performs better than axenic cultures due to robustness in metabolic function (Bhatt et al., 2019b). A mixed community of microorganisms can alleviate the metabolic limitations of a single population (Shong et al., 2012). In nature, microorganisms coexist as part of microbial consortia where multiple populations carry out complex chemical and physiological functions for the survival of the community (Polti et al., 2014). Natural and artificial microbial consortia are of great significance for the degradation and removal of lindane. Murthy and Manonmani (2007) developed a microbial consortium against lindane and optimized the degradation 


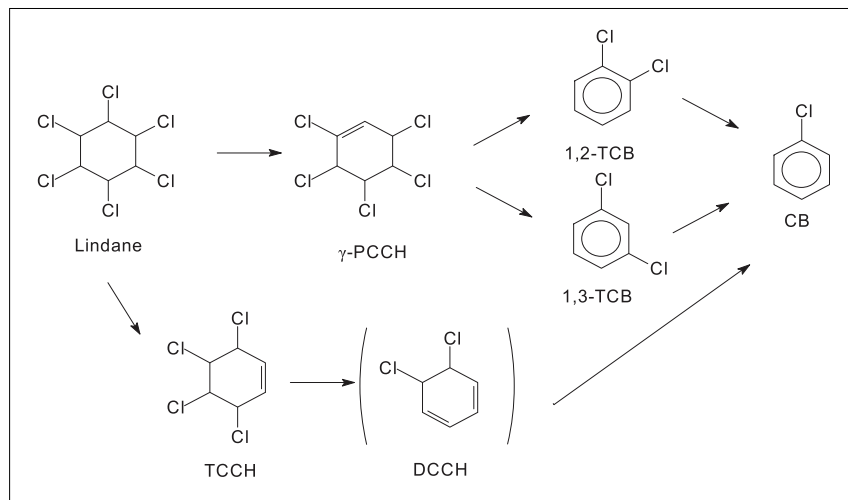

FIGURE 4 | Anaerobic degradation pathways of lindane.

conditions. The consortium rapidly degraded all concentrations of lindane up to $25 \mathrm{mg} / \mathrm{L}$.

Saez et al. (2015) evaluated the influence of a Streptomyces consortium on lindane degradation in liquid and slurry systems. An actinobacteria consortium was stable and removed 97\% of the lindane. Aparicio et al. (2017) established the optimal biological and physicochemical parameters to simultaneously remove lindane and $\mathrm{Cr}$ (VI) from the soil with an actinobacteria consortium of Streptomyces sp. M7, MC1, and A5 and Amycolatopsis tucumanensis AB0. An actinobacteria consortium was found to be superior for the degradation of lindane from a contaminated environment.

Kumar et al. (2017) conducted a bath culture degradation analysis and reported the enhanced codegradation of chlorpyrifos and lindane with two or more strains. Elcey and Kunhi (2009) isolated a lindane-degrading consortium from a sugarcane field. The consortium mineralized $300 \mu \mathrm{g} / \mathrm{mL}$ of lindane after $108 \mathrm{~h}$ of acclimation in the presence of a substrate, and no apparent accumulation of intermediary metabolites was observed.

Microbial consortiums communicated with each other via the mechanism known as quorum sensing (Ye et al., 2019, 2020). Due to this communication in the lindane-contaminated sites, the metabolic burden is divided into various members and the consortium perform complex functions. In nature, microbes coexists as communities that are affected by the local environmental conditions. Mixed microbial cultures may compete for the same resources in nature, however, they can cross feed with each other and live symbiotically with a single carbon source (Mas et al., 2016). The pesticides are degraded by the microbial consortium, which shares the metabolic labor during the degradation (Billet et al., 2019). A consortium of Streptomyces was able to efficiently degrade various chlorinated pesticides (Fuentes et al., 2013). A bacterial consortium (10 bacterial strains) was able to simultaneously degrade organophosphorous and organochlorine pesticides within 24 h (Abraham et al., 2014).

\section{Nanobiotechnology}

Currently, an integrated nanobiotechnological approach for the treatment of pesticides is gaining popularity as a novel and effective technology. Over the past decade, studies investigated the combination of nanoscale inorganic particles and microbial cells in the degradation of chlorinated hydrocarbons (Wang and Tseng, 2009). These studies proposed reductive dechlorination of lindane by nanoparticles followed by oxidative degradation of metabolites by the microbial cells. Salam and Das (2015) evaluated the effect of an embedded bio-nano hybrid system using nanoscale zinc oxide $(\mathrm{n}-\mathrm{ZnO})$ and the lindane-degrading yeast Candida VITJzN04 for lindane degradation. The bio-nano hybrid degraded lindane more effectively than the native yeasts and completely removed lindane within 3 days.

Singh et al. (2013) used an integrated nano biotechnique to combine stabilized $\mathrm{Pd} / \mathrm{Fe}(0)$ bimetallic nanoparticles [carboxymethyl cellulose (CMC)-Pd/Fe (0)] with Sphingomonas spp. strain NM05 for lindane degradation in contaminated soil. Their study signifies the potential efficacy of an integrated technique as an effective alternative remedial tool for lindanecontaminated soils. The embedded bio-nano hybrid system can be applied as an effective remediation method for the treatment of lindane-contaminated soils and wastewaters.

\section{Plant-Microbe Association}

Plants also possess a remarkable ability to remove or immobilize various environmental pollutants (Asemoloye et al., 2017). A unique chemical communication occurs between plants and their rhizospheric microbes that can be used to repair the polluted environment. In the plant-microbe relationship, plants provide habitats and nutrients for their associated bacteria. These bacteria can provide the plant with improved stress resistance, growth, and degradation of environmental pollutants (Singh and Singh, 2019b). Therefore, plant-microbe-associated bioremediation techniques were reported as cost-efficient and eco-friendly methods of cleaning polluted sites.

Sainz et al. (2010) investigated the effects of lindane pollution on vegetables and the associated arbuscular mycorrhiza. Their research indicated that the fungus increases the plant's tolerance toward the toxic effects of soil conditions. Becerra-Castro et al. (2013) inoculated substrates seeded with Cytisus striatus, Rhodococcus erythropolis ET54b, and Sphingomonas sp. D4. The results showed that the inoculation of $C$. striatus with a combination of bacterial strains is a promising approach for the remediation of lindane-contaminated sites. Asemoloye et al. (2017) isolated five dominant fungal strains from an aged lindane polluted site. Lindane degradation in polluted soil was reported to be more effective in response to the combined actions of plant roots and fungi. However, the plant-microbe association bioremediation technique for lindane degradation is still in the primary stages. There is a need for large-scale and in-depth evaluation of bioremediation protocols, as they may be useful for the remediation of lindane-polluted soils.

\section{Novel Technologies}

Traditional technologies, such as pure cultures, lack widespread application due to the low remediation capacity and sensitivity to environmental conditions. Therefore, based on the limitations of traditional technology and the modern molecular biology technology, some novel technologies that are considered to be highly efficient, eco-friendly, and promising tools were proposed to remediate the contaminated sites, for instance, metagenomics, 
genetic engineering, and enzyme engineering. With the development of new techniques, including metagenomics and genetic engineering, it becomes easy to explore new microorganisms and genes/enzymes, and these can be deployed in bioremediation programs (Kumar and Pannu, 2018).

One novel approach to enzyme immobilization is based on the entrapment of magnetic nanoparticles via epoxy cross-linking. This technique can be employed to improve the activity of pollutant degradation bacteria, fungi, or heterologous-expressed enzymes (Iype et al., 2017; Gangola et al., 2018). Recent high throughput techniques can be used to explore key functional strains from the pesticide degradation microbial community and fulfill the gap between laboratory cultures and large-scale applications (Chen et al., 2019).

Omics-based technologies provided insights into pesticide degradation (Bhatt, 2019). Advancements in next generation sequencing provide a huge amount of microbial data in the form of nucleotides and protein sequences that are deposited in various online databases (NCBI, DDBJ, Uniprot, PDB, etc.) (Bhatt and Barh, 2018). The data from the omics-based approaches can be used for the identification of novel genes and enzymes and molecular docking studies (Bhatt, 2018). These databases are also helpful for the classification of novel lindane-degrading microbes and phylogenetic analysis.

Microbial systems biology is another recent tool to study the lindane-degrading microbes and their physiology in a contaminated environment (Bhatt, 2019). The systems biology of pesticide-degrading microbial cells is helpful for understanding the detailed metabolic pathways, lindane residues in the soil/water system and their effect on other living systems. Using this tool, we can analyze the overall biomagnification due to lindane in the environment (Bhatt et al., 2019b). Systems biology tools are also helpful to design the synthetic microbial consortium for the rapid removal of lindane from soil and water bodies. With the development of modern science and technology, new technologies will continue to be developed and applied for in situ and ex situ remediation-based environmental management programs.

\section{REFERENCES}

Abhilash, P., and Singh, N. (2010). Withania somnifera Dunal-mediated dissipation of lindane from simulated soil: implications for rhizoremediation of contaminated soil. J. Soils Sediments 10, 272-282. doi: 10.1007/s11368-0090085-x

Abolhassani, M., Asadikaram, G., Paydar, P., Fallah, H., Aghaee-Afshar, M., Moazed, V., et al. (2019). Organochlorine and organophosphorous pesticides may induce colorectal cancer; a case-control study. Ecotoxicol. Environ. Saf. 178, 168-177. doi: 10.1016/j.ecoenv.2019.04.030

Abraham, J., Silambarasan, S., and Logeswari, P. (2014). Simultaneous degradation of organophosphorus and organochlorine pesticides by bacterial consortium. J. Taiwan Inst. Chem. Eng. 45, 2590-2596. doi: 10.1016/j.jtice.2014.06.014

Agrahari, A., Singh, A., Srivastava, A., Jha, R. R., Patel, D. K., Yadav, S., et al. (2019). Overexpression of cerebral cytochrome P450s in prenatally exposed offspring modify the toxicity of lindane in rechallenged offspring. Toxicol. Appl. Pharmacol. 371, 20-37. doi: 10.1016/j.taap.2019.03.022

Alvarez, A., Benimeli, C., Saez, J., Fuentes, M., Cuozzo, S., Polti, M., et al. (2012). Bacterial bio-resources for remediation of hexachlorocyclohexane. Int. J. Mol. Sci. 13, 15086-15106. doi: 10.3390/ijms131115086

\section{CONCLUSION AND FUTURE PERSPECTIVES}

Lindane, a persistent organochlorine pollutant, has become a major environmental problem around the world. Biodegradation based on the catabolic activity of pesticide-degrading microorganisms has emerged as the most cost effective, ecofriendly, and promising strategy to eliminate environmental lindane residues. The research mainly focused on the screening of lindane-degrading strains and the analysis of degradation products under laboratory conditions. A few studies reported the degradation mechanisms and practical applications of specific strains. Given the health hazards and the environmental impact of lindane, the microbial degradation-based bioremediation methods and associated technologies should be widely developed and applied. Increasing the information available regarding degradation pathways with regulatory genes and enzymes will help with the development of novel remediation technologies. Moreover, advanced molecular approaches, enzyme engineering, and emerging materials will provide better tools for the remediation of harmful pollutants.

\section{AUTHOR CONTRIBUTIONS}

SC conceived the presented idea. WZ contributed to the writing and prepared figures and table. ZL, SP, PB, and SC participated in revising the manuscript. All authors approved it for publication.

\section{FUNDING}

This study was financially supported by grants from the Key Area Research and Development Program of Guangdong Province (2018B020206001), National Natural Science Foundation of China (31401763), and Guangdong Special Branch Plan for Young Talent with Scientific and Technological Innovation (2017TQ04N026).

Anupama, K., and Paul, S. (2009). Ex situ and in situ biodegradation of lindane by Azotobacter chroococcum. J. Environ. Sci. Health Part B 45, 58-66. doi: 10.1080/03601230903404465

Aparicio, J., Solá, M. Z. S., Benimeli, C. S., Amoroso, M. J., and Polti, M. A. (2015). Versatility of Streptomyces sp. M7 to bioremediate soils co-contaminated with Cr (VI) and lindane. Ecotoxicol. Environ. Saf. 116, 34-39. doi: 10.1016/j.ecoenv. 2015.02.036

Aparicio, J. D., Benimeli, C. S., Almeida, C. A., Polti, M. A., and Colin, V. L. (2017). Integral use of sugarcane vinasse for biomass production of actinobacteria: potential application in soil remediation. Chemosphere 181, 478-484. doi: 10. 1016/j.chemosphere.2017.04.107

Arora, P. K., Srivastava, A., Garg, S. K., and Singh, V. P. (2017). Recent advances in degradation of chloronitrophenols. Bioresour. Technol. 250, 902-909. doi: 10.1016/j.biortech.2017.12.007

Asemoloye, M. D., Ahmad, R., and Jonathan, S. G. (2017). Synergistic rhizosphere degradation of $\gamma$-hexachlorocyclohexane (lindane) through the combinatorial plant-fungal action. PLoS One 12:e183373. doi: 10.1371/journal.pone.01 83373

Bajaj, S., Sagar, S., Khare, S., and Singh, D. K. (2017). Biodegradation of $\gamma$ hexachlorocyclohexane (lindane) by halophilic bacterium Chromohalobacter 
sp. LD2 isolated from HCH dumpsite. Int. Biodeterior. Biodegrad. 122, 23-28. doi: 10.1016/j.ibiod.2017.04.014

Bashir, S., Kuntze, K., Vogt, C., and Nijenhuis, I. (2018). Anaerobic biotransformation of hexachlorocyclohexane isomers by Dehalococcoides species and an enrichment culture. Biodegradation 29, 409-418. doi: 10.1007/s10532-018-9838-9

Becerra-Castro, C., Kidd, P. S., Rodríguez-Garrido, B., Monterroso, C., Santos-Ucha, P., and Prieto-Fernández, Á (2013). Phytoremediation of hexachlorocyclohexane ( $\mathrm{HCH})$-contaminated soils using Cytisus striatus and bacterial inoculants in soils with distinct organic matter content. Environ. Pollut. 178, 202-210. doi: 10.1016/j.envpol.2013.03.027

Benimeli, C., Fuentes, M., Abate, C., and Amoroso, M. (2008). Bioremediation of lindane-contaminated soil by Streptomyces sp. M7 and its effects on Zea mays growth. Int. Biodeterior. Biodegrad. 61, 233-239. doi: 10.1016/j.ibiod.2007.09. 001

Beyer, A., and Matthies, M. (2001). Long-range transport potential of semivolatile organic chemicals in coupled air-water systems. Environ. Sci. Pollut. Res. 8, 173-179. doi: 10.1007/BF02987382

Bhatt, P. (2018). "Insilico tools to study the bioremediation in microorganisms," in Handbook of Research on Microbial Tools for Environmental Waste Management, eds V. Pathak, and Navneet, (Hershey, PA: IGI Global), 389-395. doi: 10.4018/978-1-5225-3540-9.ch018

Bhatt, P. (2019). Smart Bioremediation Technologies: Microbial Enzymes. Amsterdam: Elsevier Science. doi: 10.4018/978-1-5225-3540-9.ch018

Bhatt, P., and Barh, A. (2018). "Bioinformatic tools to study the soil microorganisms: an in silico approach for sustainable agriculture," in In Silico Approach for Sustainable Agriculture, eds D. Choudhary, M. Kumar, R. Prasad, and V. Kumar, (Singapore: Springer).

Bhatt, P., Bhatt, K., Huang, Y., Lin, Z., and Chen, S. (2020a). Esterase is a powerful tool for the biodegradation of pyrethroid insecticides. Chemosphere 244:125507. doi: 10.1016/j.chemosphere.2019.125507

Bhatt, P., Huang, Y., Rene, E. R., Kumar, A. J., and Chen, S. (2020b). Mechanism of allethrin biodegradation by a newly isolated Sphingomonas trueperi strain CW3 from wastewater sludge. Bioresour. Technol. 305:123074. doi: 10.1016/j. biortech.2020.123074

Bhatt, P., Huang, Y., Zhan, H., and Chen, S. (2019a). Insight into microbial applications for the biodegradation of pyrethroid insecticides. Front. Microbiol. 10:1778. doi: 10.3389/fmicb.2019.01778

Bhatt, P., Huang, Y., Zhang, W., Sharma, A., and Chen, S. (2020c). Enhanced cypermethrin degradation kinetics and metabolic pathway in Bacillus thuringiensis strain SG4. Microorganisms 8:223. doi: 10.3390/ microorganisms 8020223

Bhatt, P., Pal, K., Bhandari, G., and Barh, A. (2019b). Modelling of the methyl halide biodegradation on bacteria and its effect on other environmental systems. Pest. Biochem. Physiol. 158, 88-100. doi: 10.1016/j.pestbp.2019. 04.015

Billet, L., Devers, M., Rouard, N., Laurent, F. M., and Spor, A. (2019). Labour sharing promotes coexistence in atrazine degrading bacterial communities. Sci. Rep. 9:18363. doi: 10.1038/s41598-019-54978-2

Camacho-Pérez, B., Ríos-Leal, E., Rinderknecht-Seijas, N., and PoggiVaraldo, H. M. (2012). Enzymes involved in the biodegradation of hexachlorocyclohexane: a mini review. J. Environ. Manage. 95, 306-318. doi: 10.1016/j.jenvman.2011.06.047

Chen, S., Chang, C., Deng, Y., An, S., Dong, Y., Zhou, J., et al. (2014). Fenpropathrin biodegradation pathway in Bacillus sp. DG-02 and its potential for bioremediation of pyrethroid-contaminated soils. J. Agric. Food. Chem. 62, 2147-2157. doi: 10.1021/jf404908j

Chen, S., Deng, Y., Chang, C., Lee, J., Cheng, Y., Cui, Z., et al. (2015). Pathway and kinetics of cyhalothrin biodegradation by Bacillus thuringiensis strain ZS-19. Sci. Rep. 5:8784. doi: 10.1038/srep08784

Chen, S., Dong, Y. H., Chang, C., Deng, Y., Xi, F. Z., Zhong, G., et al. (2013). Characterization of a novel cyfluthrin-degrading bacterial strain Brevibacterium aureum and its biochemical degradation pathway. Bioresour. Technol. 132, 16-23. doi: 10.1016/j.biortech.2013.01.002

Chen, S., Geng, P., Xiao, Y., and Hu, M. (2012). Bioremediation of $\beta$-cypermethrin and 3-phenoxybenzaldehyde contaminated soils using Streptomyces aureus HP-S-01. Appl. Microbiol. Biotechnol. 94, 505-515. doi: 10.1007/s00253-011$3640-5$
Chen, S., Hu, M., Liu, J., Zhong, G., Yang, L., Rizwan-ul-Haq, M., et al. (2011). Biodegradation of beta-cypermethrin and 3-phenoxybenzoic acid by a novel Ochrobactrum lupini DG-S-01. J. Hazard. Mater. 187, 433-440. doi: 10.1016/ j.jhazmat.2011.01.049

Chen, Y., Zhang, L., Feng, L., Chen, G., Wang, Y., Zhai, Z., et al. (2019). Exploration of the key functional strains from an azo dye degradation microbial community by DGGE and high-throughput sequencing technology. Environ. Sci. Pollut. Res. Int. 6, 24658-24671. doi: 10.1007/s11356-019-05781-z

Cuozzo, S. A., Sineli, P. E., Davila Costa, J., and Tortella, G. (2017). Streptomyces sp. is a powerful biotechnological tool for the biodegradation of $\mathrm{HCH}$ isomers: biochemical and molecular basis. Crit. Rev. Biotechnol. 38, 719-728. doi: 10. 1080/07388551.2017.1398133

Cycoń, M., Mrozik, A., and Piotrowska-Seget, Z. (2017). Bioaugmentation as a strategy for the remediation of pesticide-polluted soil: a review. Chemosphere 172, 52-71. doi: 10.1016/j.chemosphere.2016.12.129

Datta, J., Maiti, A. K., Modak, D. P., Chakrabartty, P. K., Bhattacharyya, P., and Ray, P. K. (2000). Metabolism of gamma-hexachlorocyclohexane by Arthrobacter citreus strain BI-100: Identification of metabolites. J. Gen. Appl. Microbiol. 46, 59-67. doi: 10.2323/jgam.46.59

De Paolis, M., Lippi, D., Guerriero, E., Polcaro, C., and Donati, E. (2013). Biodegradation of $\alpha-, \beta$-, and $\gamma$-hexachlorocyclohexane by Arthrobacter fluorescens and Arthrobacter giacomelloi. Appl. Biochem. Biotechnol. 170, 514524. doi: 10.1007/s12010-013-0147-9

Dominguez, C. M., Oturan, N., Romero, A., Santos, A., and Oturan, M. A. (2018a). Lindane degradation by electrooxidation process: effect of electrode materials on oxidation and mineralization kinetics. Water Res. 135, 220-230. doi: 10. 1016/j.watres.2018.02.037

Dominguez, C. M., Oturan, N., Romero, A., Santos, A., and Oturan, M. A. (2018b). Removal of lindane wastes by advanced electrochemical oxidation. Chemosphere 202, 400-409. doi: 10.1016/j.chemosphere.2018.03.124

Dritsa, V., and Rigas, F. (2013). The ligninolytic and biodegradation potential on lindane of Pleurotus ostreatus spp. J. Min. World Express 2, 23-30.

Egorova, D. O., Buzmakov, S. A., Nazarova, E. A., Andreev, D. N., Demakov, V. A., and Plotnikova, E. G. (2017). Bioremediation of hexachlorocyclohexane contaminated soil by the new Rhodococcus wratislaviensis Strain Ch628. Water Air Soil Pollut. 228:183. doi: 10.1007/s11270-017-3344-2

Elcey, C. D., and Kunhi, A. M. (2009). Substantially enhanced degradation of hexachlorocyclohexane isomers by a microbial consortium on acclimation. J. Agric. Food Chem. 58, 1046-1054. doi: 10.1021/jf9038259

Endo, R., Kamakura, M., Miyauchi, K., Fukuda, M., Ohtsubo, Y., Tsuda, M., et al. (2005). Identification and characterization of genes involved in the downstream degradation pathway of $\gamma$-hexachlorocyclohexane in Sphingomonas paucimobilis UT26. J. Bacteriol. 187, 847-853. doi: 10.1128/JB. 187.3.847-853.2005

Feng, Y., Huang, Y., Zhan, H., Bhatt, H., and Chen, S. (2020). An overview of strobilurin fungicide degradation: current status and future perspective. Front. Microbiol. 10:389. doi: 10.3389/fmicb.2020.00389

Fuentes, M. S., Briceno, G. E., Saez, J. M., Benimeli, C. S., Diez, M. C., and Amorosso, M. Z. (2013). Enhanced removal of a pesticides mixture by single cultures and consortia of free and immobilized Streptomyces strains. Biomed Res. Int. 2013:392573. doi: 10.1155/2013/392573

Gangola, S., Sharma, A., Bhatt, P., Khati, P., and Chaudhary, P. (2018). Presence of esterase and laccase in Bacillus subtilis facilitates biodegradation and detoxification of cypermethrin. Sci. Rep. 8:12755. doi: 10.1038/s41598-01831082-5

Geueke, B., Garg, N., Ghosh, S., Fleischmann, T., Holliger, C., Lal, R., et al. (2013). Metabolomics of hexachlorocyclohexane $(\mathrm{HCH})$ transformation: ratio of LinA to LinB determines metabolic fate of $\mathrm{HCH}$ isomers. Environ. Microbiol. 15, 1040-1049. doi: 10.1111/1462-2920.12009

Giri, K., Rawat, A. P., Rawat, M., and Rai, J. (2014). Biodegradation of hexachlorocyclohexane by two species of bacillus isolated from contaminated soil. Chem. Ecol. 30, 97-109. doi: 10.1080/02757540.2013. 844795

Githinji, I. N. (2015). Screening and Isolation of $\gamma$-Hexachlorocyclohexane Degrading Bacteria from Contaminated Soil in Kenya. Nairobi: University of Nairobi. doi: 10.1080/02757540.2013.844795

Guillén-Jiménez, F. D. M., Cristiani-Urbina, E., Cancino-Díaz, J. C., FloresMoreno, J. L., and Barragán-Huerta, B. E. (2012). Lindane biodegradation by 
the Fusarium verticillioides AT-100 strain, isolated from Agave tequilana leaves: kinetic study and identification of metabolites. Int. Biodeterior. Biodegrad. 74, 36-47. doi: 10.1016/j.ibiod.2012.04.020

Huang, Y., Zhan, H., Bhatt, P., and Chen, S. (2019). Paraquat degradation from contaminated environments: current achievements and perspectives. Front. Microbiol. 10:1754. doi: 10.3389/fmicb.2019.01754

Iype, T., Thomas, J., Mohan, S., Johnson, K. K., George, L. E., Ambattu, L. A., et al. (2017). A novel method for immobilization of proteins via entrapment of magnetic nanoparticles through epoxy cross-linking. Anal. Biochem. 519, 42-50. doi: 10.1016/j.ab.2016.12.007

Jan, K., Kamila, H., Tomás, J., Yuji, N., Ana, N., Federico, G., et al. (2005). Quantitative analysis of substrate specificity of haloalkane dehalogenase LinB from Sphingomonas paucimobilis UT26. Biochemistry 44, 3390-3401. doi: 10. 1021/bi047912o

Janssen, D. B. (2004). Evolving haloalkane dehalogenases. Curr. Opin. Chem. Biol. 8, 150-159. doi: 10.1016/j.cbpa.2004.02.012

Jayaraj, R., Megha, P., and Sreedev, P. (2016). Organochlorine pesticides, their toxic effects on living organisms and their fate in the environment. Interdiscip. Toxicol. 9, 90-100. doi: 10.1515/intox-2016-0012

Jung, H. J., Koutavarapu, R., Lee, S., Kim, J. H., Choi, H. C., and Choi, M. Y. (2018). Enhanced photocatalytic degradation of lindane using metal-semiconductor Zn@ ZnO and ZnO/Ag nanostructures. J. Environ. Sci. 74, 107-115. doi: 10. 1016/j.jes.2018.02.014

Kaur, H., and Kaur, G. (2016). Application of ligninolytic potentials of a white-rot fungus Ganoderma lucidum for degradation of lindane. Environ. Monit. Assess. 188:588. doi: 10.1007/s10661-016-5606-7

Keisuke, M., Haeng-Seog, L., Masao, F., Masamichi, T., and Yuji, N. (2002). Cloning and characterization of linR, involved in regulation of the downstream pathway for gamma-hexachlorocyclohexane degradation in Sphingomonas paucimobilis UT26. Mol. Immunol. 68, 1803-1807. doi: 10.1128/AEM.68.4. 1803-1807.2002

Kumar, D. (2018). Biodegradation of $\gamma$-Hexachlorocyclohexane by Burkholderia sp. IPL04. Biocatal. Agric. Biotechnol. 16, 331-339. doi: 10.1016/j.bcab.2018.09. 001

Kumar, D., Jaswal, S., and Chopra, S. (2017). Co-degradation study of lindane and chlorpyrifos by novel bacteria. Int. J. Environ. Waste Manag. 20, 283-299. doi: 10.1504/IJEWM.2017.090050

Kumar, D., Kumar, A., and Sharma, J. (2016). Degradation study of lindane by novel strains Kocuria sp. DAB-1Y and Staphylococcus sp. DAB-1W. Bioresour. Bioprocess. 3:53. doi: 10.1186/s40643-016-0130-8

Kumar, D., and Pannu, R. (2018). Perspectives of lindane ( $\gamma$ hexachlorocyclohexane) biodegradation from the environment: a review. Bioresour. Bioprocess. 5:29. doi: 10.1186/s40643-018-0213-9

Kumar, M., Gupta, S. K., Garg, S. K., and Kumar, A. (2011). Biodegradation of hexachlorocyclohexane-isomers in contaminated soils. Soil Biol. Biochem. 38, 2318-2327. doi: 10.1016/j.soilbio.2006.02.010

Lal, R., Dogra, C., Malhotra, S., Sharma, P., and Pal, R. (2006). Diversity, distribution and divergence of lin genes in hexachlorocyclohexane-degrading sphingomonads. Trends Biotechnol. 24, 121-130. doi: 10.1016/j.tibtech.2006.01. 005

Lal, R., Pandey, G., Sharma, P., Kumari, K., Malhotra, S., Pandey, R., et al. (2010). Biochemistry of microbial degradation of hexachlorocyclohexane and prospects for bioremediation. Microbiol. Mol. Biol. Rev. 74, 58-80. doi: 10.1128/MMBR. 00029-09

Lin, Z., Zhang, W., Pang, S., Huang, Y., Mishra, S., Bhatt, P., et al. (2020). Current approaches to and future perspectives on methomyl degradation in contaminated soil/water environments. Molecules 25:738. doi: 10.3390/ molecules 25030738

Liu, J., Chen, S., Ding, J., Xiao, Y., Han, H., and Zhong, G. (2015). Sugarcane bagasse as support for immobilization of Bacillus pumilus HZ-2 and its use in bioremediation of mesotrione-contaminated soils. Appl. Microbiol. Biotechnol. 99, 10839-10851. doi: 10.1007/s00253-015-6935-0

Loredana, S., Graziano, P., Antonio, M., Carlotta, N. M., Caterina, L., Maria, A. A., et al. (2017). Lindane bioremediation capability of bacteria associated with the demosponge Hymeniacidon perlevis. Mar. Drugs 15:E108. doi: 10.3390/ md15040108

Luo, D., Pu, Y., Tian, H., Cheng, J., Zhou, T., Tao, Y., et al. (2016). Concentrations of organochlorine pesticides in umbilical cord blood and related lifestyle and dietary intake factors among pregnant women of the Huaihe River Basin in China. Environ. Int. 92, 276-283. doi: 10.1016/j.envint.2016.04.017

Manickam, N., Mau, M., and Schlömann, M. (2006). Characterization of the novel HCH-degrading strain, Microbacterium sp. ITRC1. Appl. Microbiol. Biotechnol. 69, 580-588. doi: $10.1007 / \mathrm{s} 00253-005-0162-\mathrm{z}$

Manickam, N., Misra, R., and Mayilraj, S. (2010). A novel pathway for the biodegradation of gamma-hexachlorocyclohexane by a Xanthomonas sp. strain ICH12. J. Appl. Microbiol. 102, 1468-1478. doi: 10.1111/j.1365-2672.2006. 03209.x

Manickam, N., Reddy, M., Saini, H., and Shanker, R. (2008). Isolation of hexachlorocyclohexane-degrading Sphingomonas sp. by dehalogenase assay and characterization of genes involved in $\gamma$-HCH degradation. J. Appl. Microbiol. 104, 952-960. doi: 10.1111/j.1365-2672.2007.03610.x

Markman, S., Guschina, I. A., Barnsley, S., Buchanan, K. L., Pascoe, D., and Müller, C. T. (2007). Endocrine disrupting chemicals accumulate in earthworms exposed to sewage effluent. Chemosphere 70, 119-125. doi: 10.1016/ j.chemosphere.2007.06.045

Mas, A., Jamshidi, S., Lagadeuc, Y., Eveillard, D., and Vandenkoornhuyse, P. (2016). Beyond the black queen hypothesis. ISME J. 10, 2085-2093. doi: 10.1038/ismej. 2016.22

Mladenović, D., Djuric, D., Petronijević, N., Radosavljević, T., Radonjić, N., Matić, D., et al. (2010). The correlation between lipid peroxidation in different brain regions and the severity of lindane-induced seizures in rats. Mol. Cell. Biochem. 333:243. doi: 10.1007/s11010-009-0225-z

Mortazavi, N., Asadikaram, G., Ebadzadeh, M. R., Kamalati, A., Pakmanesh, H., Dadgar, R., et al. (2019). Organochlorine and organophosphorus pesticides and bladder cancer: a case-control study. J. Cell. Biochem. 120, 14847-14859. doi: $10.1002 /$ jcb. 28746

Muñiz, S., Gonzalvo, P., Valdehita, A., Molina-Molina, J. M., Navas, J. M., Olea, N., et al. (2017). Ecotoxicological assessment of soils polluted with chemical waste from lindane production: use of bacterial communities and earthworms as bioremediation tools. Ecotoxicol. Environ. Saf. 145, 539-548. doi: 10.1016/j. ecoenv.2017.07.070

Murthy, H. M. R., and Manonmani, H. K. (2007). Aerobic degradation of technical hexachlorocyclohexane by a defined microbial consortium. J. Hazard. Mater. 149, 18-25. doi: 10.1016/j.jhazmat.2007.03.053

Nagata, Y., Endo, R., Ito, M., Ohtsubo, Y., and Tsuda, M. (2007). Aerobic degradation of lindane ( $\gamma$-hexachlorocyclohexane) in bacteria and its biochemical and molecular basis. Appl. Microbiol. Biotechnol. 76, 741-752. doi: 10.1007/s00253-007-1066-X

Nagpal, V., and Paknikar, K. (2006). Integrated biological approach for the enhanced degradation of lindane. J. Basic Microbiol. 56, 820-826. doi: 10.1002/ jobm.201500559

Nagpal, V., Srinivasan, M., and Paknikar, K. (2008). Biodegradation of $\gamma$ hexachlorocyclohexane (Lindane) by a non-white rot fungus Conidiobolus 03-1-56 isolated from litter. Indian J. Microbiol. 48, 134-141. doi: 10.1007/ s12088-008-0013-6

Nanasato, Y., Namiki, S., Oshima, M., Moriuchi, R., Konagaya, K.-I., Seike, N., et al. (2016). Biodegradation of $\gamma$-hexachlorocyclohexane by transgenic hairy root cultures of Cucurbita moschata that accumulate recombinant bacterial LinA. Plant Cell Rep. 35, 1963-1974. doi: 10.1007/s00299-0162011-1

Nolan, K., Kamrath, J., and Levitt, J. (2012). Lindane toxicity: a comprehensive review of the medical literature. Pediatr. Dermatol. 29, 141-146. doi: 10.1111/j. 1525- 1470.2011.01519.x

Padhi, S., and Pati, B. (2016). Severity of persistence and toxicity of hexachlorocyclohexane $(\mathrm{HCH})$ to the environment-A current approach. Scholarly Res. J. Interdiscip. Stud. 4, 3158-3168.

Pamela, C., Andrea, S. D., Nadin, U., Uwe, S. T., Albrecht, P., Gerrit, S., et al. (2011). Determination of lindane leachability in soil-biosolid systems and its bioavailability in wheat plants. Chemosphere 84, 397-402. doi: 10.1016/j. chemosphere.2011.03.070

Polti, M. A., Aparicio, J. D., Benimeli, C. S., and Amoroso, M. J. (2014). Simultaneous bioremediation of $\mathrm{Cr}$ (VI) and lindane in soil by actinobacteria. Int. Biodeterior. Biodegrad. 88, 48-55. doi: 10.1016/j.ibiod.2013. 12.004

Quintero, J. C., Lu-Chau, T. A., Moreira, M. T., Feijoo, G., and Lema, J. M. (2007). Bioremediation of $\mathrm{HCH}$ present in soil by the white-rot fungus Bjerkandera 
adusta in a slurry batch bioreactor. Int. Biodeterior. Biodegrad. 60, 319-326. doi: 10.1016/j.ibiod.2007.05.005

Quintero, J. C., Moreira, M. T., Feijoo, G., and Lema, J. M. (2005a). Anaerobic degradation of hexachlorocyclohexane isomers in liquid and soil slurry systems. Chemosphere 61, 528-536. doi: 10.1016/j.chemosphere.2005.02.010

Quintero, J. C., Moreira, M. T., Feijoo, G., and Lema, J. M. (2005b). Effect of surfactants on the soil desorption of hexachlorocyclohexane $(\mathrm{HCH})$ isomers and their anaerobic biodegradation. J. Chem. Technol. Biotechnol. 80, 10051015. doi: $10.1002 /$ jctb. 1277

Rinku, P., Shashi, B., Mandeep, D., Mukesh, K., Gauri, D., Om, P., et al. (2005). Hexachlorocyclohexane-degrading bacterial strains Sphingomonas paucimobilis B90A, UT26 and Sp+, having similar lin genes, represent three distinct species, Sphingobium indicum sp. nov., Sphingobium japonicum sp. nov. and Sphingobium francense sp. nov., and reclassification of [Sphingomonas] chungbukensis as Sphingobium chungbukense comb. nov. Int. J. Syst. Evol. Microbiol. 55, 1965-1972. doi: 10.1099/ijs.0.63201-0

Saez, J., Alvarez, A., Fuentes, M., Amoroso, M., and Benimeli, C. (2017). "An overview on microbial degradation of lindane," in Microbe-Induced Degradation of Pesticides, ed. S. Singh, (Cham: Springer), 191-212. doi: 10.1007/978-3-31945156-5_9

Saez, J. M., Aparicio, J. D., Amoroso, M. J., and Benimeli, C. S. (2015). Effect of the acclimation of a Streptomyces consortium on lindane biodegradation by free and immobilized cells. Process Biochem. 50, 1923-1933. doi: 10.1016/j.procbio. 2015.08.014

Saez, J. M., Bigliardo, A. L., Raimondo, E. E., Briceño, G. E., Polti, M. A., and Benimeli, C. S. (2018). Lindane dissipation in a biomixture: effect of soil properties and bioaugmentation. Ecotoxicol. Environ. Saf. 156, 97-105. doi: 10.1016/j.ecoenv.2018.03.011

Sagar, V., and Singh, D. (2011). Biodegradation of lindane pesticide by non whiterots soil fungus Fusarium sp. World J Microbiol. Biotechnol. 27, 1747-1754. doi: $10.1007 / \mathrm{s} 11274-010-0628-8$

Sahoo, B., Ningthoujam, R., and Chaudhuri, S. (2019). Isolation and characterization of a lindane degrading bacteria Paracoccus sp. NITDBR1 and evaluation of its plant growth promoting traits. Int. Microbiol. 22, 155-167. doi: 10.1007/s10123-018-00037-1

Sainz, M. J., Gonzalez-Penalta, B., and Vilarino, A. (2010). Effects of hexachlorocyclohexane on rhizosphere fungal propagules and root colonization by arbuscular mycorrhizal fungi in Plantago lanceolata. Eur. J. Soil Sci. 57, 83-90. doi: $10.1111 / \mathrm{j} .1365-2389.2005 .00775 . \mathrm{x}$

Salam, J. A., and Das, N. (2015). Degradation of lindane by a novel embedded bionano hybrid system in aqueous environment. Appl. Microbiol. Biotechnol. 99, 2351-2360. doi: 10.1007/s00253-014-6112-x

Salam, J. A., Hatha, M. A., and Das, N. (2017). Microbial-enhanced lindane removal by sugarcane (Saccharum officinarum) in doped soil-applications in phytoremediation and bioaugmentation. J. Environ. Manage. 193, 394-399. doi: 10.1016/j.jenvman.2017.02.006

Salam, J. A., Lakshmi, V., Das, D., and Das, N. (2013). Biodegradation of lindane using a novel yeast strain, Rhodotorula sp. VITJzN03 isolated from agricultural soil. World J. Microbiol. Biotechnol. 29, 475-487. doi: 10.1007/s11274-0121201-4

Sangwan, N., Lata, P., Dwivedi, V., Singh, A., Niharika, N., Kaur, J., et al. (2012). Comparative metagenomic analysis of soil microbial communities across three hexachlorocyclohexane contamination levels. PLoS One 7:e46219. doi: 10.1371/ journal.pone.0046219

Sharma, P., Shankar, S., Agarwal, A., and Singh, R. (2010). Variation in serum lipids and liver function markers in lindane exposed female wistar rats: attenuating effect of curcumin, vitamin C and vitamin E. Asian J. Exp. Biol. Sci. 1, 440-444.

Shong, J., Diaz, M. R. J., and Collins, C. H. (2012). Towards synthetic microbial consortia for bioprocessing. Curr. Opin. Biotechnol. 23, 798-802. doi: 10.1016/ j.copbio.2012.02.001

Sineli, P. E., Tortella, G., Costa, J. D., Benimeli, C. S., and Cuozzo, S. A. (2016). Evidence of $\alpha-, \beta$-and $\gamma-\mathrm{HCH}$ mixture aerobic degradation by the native actinobacteria Streptomyces sp. M7. World J. Microbiol. Biotechnol. 32:81. doi: 10.1007/s11274-016-2037-0

Singh, B. K., and Kuhad, R. C. (2000). Degradation of insecticide lindane $(\gamma-\mathrm{HCH})$ by white-rot fungi Cyathus bulleri and Phanerochaete sordida. Pest Manag. Sci. 56, 142-146. doi: 10.1002/1526-4998(200002)56\%3A2\%3C142\%3A\%3Aaidps104\%3E3.0.co\%3B2-i
Singh, R., Manickam, N., Mudiam, M. K. R., Murthy, R. C., and Misra, V. (2013). An integrated (nano-bio) technique for degradation of $\gamma$-HCH contaminated soil. J. Hazard. Mater. 258, 35-41. doi: 10.1016/j.jhazmat.2013.04.016

Singh, T., and Singh, D. K. (2019a). Lindane degradation by root epiphytic bacterium Achromobacter sp. strain A3 from Acorus calamus and characterization of associated proteins. Int. J. Phytoremediat. 21, 419-424. doi: $10.1080 / 15226514.2018 .1524835$

Singh, T., and Singh, D. K. (2019b). Rhizospheric Microbacterium sp. P27 showing potential of lindane degradation and plant growth promoting traits. Curr. Microbiol. 76, 888-895. doi: 10.1007/s00284-019-01703-x

Sun, G., Du, Y., Yin, J., Jiang, Y., Zhang, D., Jiang, B., et al. (2019). Response of microbial communities to different organochlorine pesticides $(\mathrm{O})$ contamination levels in contaminated soils. Chemosphere 215, 461-469. doi: 10.1016/j.chemosphere.2018.09.160

Tsygankov, V. Y., Lukyanova, O., Boyarova, M., Gumovskiy, A., Donets, M., Lyakh, V., et al. (2019). Organochlorine pesticides in commercial Pacific salmon in the Russian Far Eastern seas: food safety and human health risk assessment. Mar. Pollut. Bull. 140, 503-508. doi: 10.1016/j.marpolbul.2019.02.008

Usman, M., Tascone, O., Faure, P., and Hanna, K. (2014). Chemical oxidation of hexachlorocyclohexanes (HCHs) in contaminated soils. Sci. Total Environ. 476, 434-439. doi: 10.1016/j.scitotenv.2014.01.027

Vankar, P. S., and Ramashanker, S. (2011). Lindane levels in the dumping grounds in Chinhat area, Lucknow, India. Elecron. J. Environ. Agric. Food. Chem. 10, 2081-2089.

Vega, M., Romano, D., and Uotila, E. (2016). Lindane (persistent organic pollutant) in the EU. Directorate General for Internal Policies. Policy Department C: Citizens' Rights and Constitutional Affairs. Petitions. PE 571.398. Available at: https://www.europarl.europa.eu/RegData/etudes/STUD/ 2016/571398/IPOL_STU(2016)571398_EN.pdf (accessed August 16, 2019).

Vijgen, J., Abhilash, P., Li, Y. F., Lal, R., Forter, M., Torres, J., et al. (2011). Hexachlorocyclohexane $(\mathrm{HCH})$ as new Stockholm Convention POPs-a global perspective on the management of Lindane and its waste isomers. Environ. Sci. Pollut. Res. 18, 152-162. doi: 10.1007/s11356-010-0417-9

Vijgen, J., de Borst, B., Weber, R., Stobiecki, T., and Forter, M. (2019). HCH and lindane contaminated sites: European and global need for a permanent solution for a long-time neglected issue. Environ. Pollut. 248, 696-705. doi: 10.1016/j.envpol.2019.02.029

Vijgen, J., Weber, R., Lichtensteiger, W., and Schlumpf, M. (2018). The legacy of pesticides and POPs stockpiles-a threat to health and the environment. Environ. Sci. Pollut. Res. 25, 31793-31798. doi: 10.1007/s11356-018-3188-3

Wacławek, S., Antoš, V., Hrabák, P., and Černík, M. (2016). Remediation of hexachlorocyclohexanes by cobalt-mediated activation of peroxymonosulfate. Desalin. Water Treat. 57, 26274-26279. doi: 10.1080/19443994.2015.1119757

Wang, C. W., Chang, S. C., and Liang, C. (2019). Persistent organic pollutant lindane degradation by alkaline cold-brew green tea. Chemosphere 232, 281286. doi: 10.1016/j.chemosphere.2019.05.187

Wang, S. M., and Tseng, S. K. (2009). Reductive dechlorination of trichloroethylene by combining autotrophic hydrogen-bacteria and zero-valent iron particles. Bioresour. Technol. 100, 111-117. doi: 10.1016/j.biortech.2008. 05.033

Wang, X. L. (2019). Joint multi-departmental submission: prohibition on production, circulation, application, import and export of pesticides such as lindane. Mod. Agrochem. 18:44.

Weber, R., Aliyeva, G., and Vijgen, J. (2013). The need for an integrated approach to the global challenge of POPs management. Environ. Sci. Pollut. Res. 20, 1901-1906. doi: 10.1007/s11356-012-1247-8

Yang, J., Feng, Y., Zhan, H., Liu, J., Yang, F., Zhang, K., et al. (2018). Characterization of a pyrethroid-degrading Pseudomonas fulva strain P31 and biochemical degradation pathway of D-phenothrin. Front. Microbiol. 9:1003. doi: $10.3389 /$ fmicb. 2018.01003

Ye, T., Zhou, T., Li, Q., Xu, X., Fan, X., Zhang, L., et al. (2020). Cupriavidus sp. HN-2, a novel quorum quenching bacterial isolate, is a potent biocontrol agent against Xanthomonas campestris pv. campestris. Microorganisms 8:E45. doi: $10.3390 /$ microorganisms 8010045

Ye, T., Zhou, T., Fan, X., Bhatt, P., Zhang, L., and Chen, S. (2019). Acinetobacter lactucae strain QL-1, a novel quorum quenching candidate against bacterial pathogen Xanthomonas campestris pv. campestris. Front. Microbiol. 10:2867. doi: $10.3389 /$ fmicb.2019.02867 
Zhang, H., Chen, F., Zhao, H., Lu, J., Zhao, M., Hong, Q., et al. (2018). Colonization on cucumber root and enhancement of chlorimuron-ethyl degradation in the rhizosphere by Hansschlegelia zhihuaiae S113 and root exudates. J. Agric. Food Chem. 66, 4584-4591. doi: 10.1021/acs.jafc.8b00041

Zhan, H., Huang, Y., Lin, Z., Bhatt, P., and Chen, S. (2020). New insights into the microbial degradation and catalytic mechanism of synthetic pyrethroids. Environ. Res. 182:109138. doi: 10.1016/j.envres.2020.10 9138

Zhan, H., Feng, Y., Fan, X., and Chen, S. (2018a). Recent advances in glyphosate biodegradation. Appl. Microbiol. Biotechnol. 102, 5033-5043. doi: 10.1007/ s00253-018-9035-0

Zhan, H., Wang, H., Liao, L., Feng, Y., Fan, X., Zhang, L., et al. (2018b). Kinetics and novel degradation pathway of permethrin in Acinetobacter baumannii ZH-14. Front. Microbiol. 9:98. doi: 10.3389/fmicb.2018. 00098

Zhang, J., Lu, L., Chen, F., Chen, L., Yin, J., and Huang, X. (2018). Detoxification of diphenyl ether herbicide lactofen by Bacillus sp. Za and enantioselective characteristics of an esterase gene lacE. J. Hazard. Mater. 341, 336-345. doi: 10.1016/j.jhazmat.2017.07.064

Zhang, W., Ye, Y., Hu, D., Ou, L., and Wang, X. (2010). Characteristics and transport of organochlorine pesticides in urban environment: air, dust, rain, canopy throughfall, and runoff. J. Environ. Monit. 12, 2153-2160. doi: 10.1039/ c0em00110d

Conflict of Interest: The authors declare that the research was conducted in the absence of any commercial or financial relationships that could be construed as a potential conflict of interest.

Copyright (c) 2020 Zhang, Lin, Pang, Bhatt and Chen. This is an open-access article distributed under the terms of the Creative Commons Attribution License (CC BY).

The use, distribution or reproduction in other forums is permitted, provided the original author(s) and the copyright owner(s) are credited and that the original publication in this journal is cited, in accordance with accepted academic practice. No use, distribution or reproduction is permitted which does not comply with these terms. 